\title{
EFEKTIVITAS PENGGUNAAN BUILDING BLOCKS "LEGO" UNTUK MENINGKATKAN KEMAMPUAN MOTORIK HALUS ANAK USIA DINI
}

\author{
Ika Apriati W.P., M. Psi, Psikolog ${ }^{1}$, Marselina Huring, S. Pd ${ }^{2}$ \\ ${ }^{1,2}$ Universitas Widya Gama Mahakam Samarinda \\ 1ikaapriati@uwgm.ac.id, ${ }^{2}$ huring27@gmail.com
}

\begin{abstract}
Abstrak
The purpose of this research is to know the effectiveness of building blocks "Lego" to enhance the visual ability of the motor in early childhood. This research uses the Pre Experimental Design method or is also commonly known as Quasi Experiment. The form of experimental design used is The One Group Pretest-posttest Design. The implementation of this research uses single-group design with Pretests and Posttest conducted by conducting experiments on one group, without the use of comparative groups. The subject of this study was children who participated in a Lego course in Robokidz Samarinda for 3 people, aged 5-6 years. Measuring instruments In this study use the child's fine motor Development observation sheet and semi-structured interviews with teachers. The results showed that the use of building blocks "Lego" does not improve the fine motor capability of early childhood significantly $(z=-1,414, p=0157)$. However, the subject shows a trend for the improvement of fine motor capability indicated by the increase in the child's fine motor proficiency score.
\end{abstract}

Keywords: building blocks "Lego", motor skills, fine motor

\section{Pendahuluan}

Salah satu aspek perkembangan yang cukup penting untuk dikembangkan adalah perkembangan motorik. Sayangnya, di era kemajuan teknologi sekarang ini, perkembangan motorik anak cenderung tidak terstimulasi secara optimal. Saat ini, anak banyak sekali terpapar teknologi berupa penggunaan gadget, yang kebanyakan hanya memberikan stimulasi kognitif saja, sehingga kurang mengasah perkembangan motorik mereka.

Perkembangan motorik pada anak meliputi motorik kasar dan halus. Perkembangan motorik halus yaitu gerakan yang menggunakan otot-otot halus yang berkoordinasi dengan otak dalam melakukan sesuatu kegiatan. Gerakan motorik halus hanya melibatkan bagian- bagian tertentu saja dan dilakukan oleh otototot halus, seperti keterampilan menggunakan jari jemari tangan dan gerakan pergelangan tangan yang tepat. kemampuan motorik halus maka akan melatih mengkoordinasikan gerakan visual motorik, seperti mengkoordinasikan gerakan mata dengan tangan, lengan, dan tubuh secara bersamaan, antara lain dapat dilihat pada waktu anak menulis atau menggambar. Apabila kemampuan motorik halus anak tidak dikembangkan maka anak tidak dapat menghibur dirinya dan memperoleh perasaan senang. Seperti anak menjadi murung karena tidak memiliki ketrampilan menulis, mewarnai, mencocok, menggunting, melipat, bongkar pasang, bermain puzzle serta memainkan alat-alat mainan yang ia sukai. 
Keterampilan motorik tidak akan berkembang melalui kematangan saja. Melainkan keterampilan itu harus dipelajari. Hal penting dalam mempelajari keterampilan motorik (Hurlock dalam Yenny, 2017) :

a. Kesempatan belajar. Banyak anak yang tidak berkesempatan untuk mempelajari keterampilan motorik karena hidup dalam lingkungan yang tidak menyediakan kesempatan belajar.

b. Kesempatan berpraktek. Anak harus diberi waktu untuk berpraktek sebanyak yang diperlukan untuk menguasai suatu keterampilan.

Menurut Gallahue dan Ozmun (Widiyanti, 2016) menyebutkan bahwa perkembangan motorik anak memiliki fase yang berbeda-beda sesuai dengan rentang umur anak. Pada setiap fase yang dilalui, anak akan mengalami kegiatan-kegiatan motorik yang berbeda-beda dan tingkat kesukaran yang berbeda-beda pula. Pada setiap fase perkembangan tersebut anak harus mendapatkan rangsangan yang baik agar bisa melewati fase tersebut dengan mendapatkan hasil yang maksimal bagi pertumbuhan dan perkembangannya.

Perkembangan motorik halus bukan hanya terkait dengan perkembangan fleksibilitas tangan dan jari-jemari untuk melakukan aktivitas seperti menyuapkan makanan ke mulut, menulis, menggambar, berpakaian maupun bermain dengan permainan yang membutuhkan koordinasi tangan. Tetapi motorik halus juga termasuk koordinasi otot-otot kecil di daerah seperti lidah, bibir, dan otot-otot pipi. Sedangkan pada usia 5 tahun, koordinasi motorik halus pada anak lebih meningkat lagi. Tangan, lengan, dan tubuh semua bergerak bersama dengan lebih baik di bawah komando mata (Santrock dalam Putri, Antara, \& Tirtayani, 2016).

Rumini dan Sundari (2004) mengemukakan bahwa faktor-faktor yang mempengaruhi kemampuan motorik halus adalah sebagi berikut:

a. Faktor genetika, individu mempunyai beberapa faktor keturunan yang dapat menunjang kemampuan motorik halus misalnya otot kuat, syaraf baik, kecerdasan yang menyebabkan kemampuan motorik individu tersebut menjadi baik dan cepat.

b. Faktor kesehatan pada periode prenatal, janin yang selama dalam kandungan dalam keadaan sehat, tidak keracunan, tidak kekurangan gizi, tidak kekurangan vitamin dapat membantu mempelancar kemampuan motorik anak

c. Faktor kesehatan gizi, kesehatan dan gizi yang baik pada awal kehidupan pasca melahirkan akan mempercepat kemampuan motorik bayi.

d. Faktor rangsangan, adanya rangsangan bimbingan orang tua dan kesempatan anak untuk menggerakkan semua bagian tubuh akan mempercepat kemampuan motorik bayi.

e. Faktor kebudayaan, peraturan daerah setempat dapat mempengaruhi kemampuan motorik anak misalnya ada daerah yang tidak mengizinkan anak putri naik sepeda maka tidak akan diberi pelajaran naik sepeda roda tiga. 
Salah satu bentuk permainan yang dapat digunakan untuk meningkatkan kemampuan motorik halus anak adalah dengan menggunakan building block "Lego". Building block "Lego" merupakan sejenis permainan bongkah plastik yang terkenal di kalangan anak-anak. Bongkahbongkah ini serta kepingan lain dapat disusun menjadi model apa saja, seperti mobil, kereta api, bangunan, kota, patung, pesawat terbang, robot, dan lain-lain. Melalui permainan "Lego" anak dapat melatih keterampilan motorik halusnya, melatih konsentrasi, ketekunan dan daya tahan. Dengan permainan ini koordinasi syaraf, otot-otot halus terlatih, sehingga gerakan jari jemarinya lebih terampil yang akan bermanfaat untuk melanjutkan pendidikan yang lebih tinggi dan pengembangan keterampilan di masa yang akan datang.Melalui permainan Lego anak dapat melatih keterampilan motorik halusnya, melatih konsentrasi, ketekunan dan daya tahan. Dengan permainan ini koordinasi syaraf, otot-otot halus terlatih, sehingga gerakan jari jemarinya lebih terampil yang akan bermanfaat dikehidupannya kelak (Martuti, 2008).

Tujuan dari penelitian ini adalah untuk mendeskripsikan dan mengukur efektivitas penggunaan building blocks "LEGO" dalam meningkatkan kemampuan motorik halus anak usia dini. Efektivitas akan diukur dari perbedaan kemampuan motorik halus anak sebelum diberikan building blocks "LEGO" dengan setelah diberikan building blocks "LEGO" selama 8 minggu. Berdasarkan hal tersebut, maka hipotesis dari penelitian ini adalah building blocks "LEGO" meningkatkan kemampuan motorik halus anak usia dini.

\section{Metode}

Subjek penelitian ini adalah anakanak yang mengikuti kursus lego di Robokidz Samarinda sebanyak 3 orang dengan kriteria inklusi sebagai berikut :

a. Berusia 5-6 tahun

b. Berada pada level Kindergarten B di Robokidz Samarinda

Variabel bebas penelitian adalah building blocks "Lego" yaitu sejenis mainan bongkar pasang yang biasanya terbuat dari plastik kecil, yang biasanya cukup terkenal di kalangan anak-anak, dan kepingankepingan lego tersebut dapat disusun menjadi model apa saja, seperti rumah, mobil, kreta api, kota patung, kapal, pesawat, robot dan lain-lain.

Variabel tergantung penelitian adalah kemampuan motorik halus anak. Kemampuan motorik halus adalah kemampuan anak untuk mengamati sesuatu dan melakukan gerak yang melibatkan bagian-bagian tubuh tertentu dan otot-otot kecil, memerlukan koordinasi yang cermat serta tidak memerlukan banyak tenaga.

Pengukuran dalam penelitian ini menggunakan beberapa instrumen, yaitu:

a. Lembar observasi kemampuan motorik halus anak berdasarkan Permendikbud 137 Tahun 2014 untuk mengukur peningkatan kemampuan motorik halus anak sebelum dan sesudah intervensi diberikan.

b. Wawancara semi-terstruktur yang dilakukan kepada guru di Robokidz untuk mendapatkan data kualitatif mengenai efek intervensi yang diberikan

Penelitian ini menggunakan metode Pre Experimental Design atau juga sering 
dikenal dengan Quasi Experiment. Bentuk rancangan eksperimen yang digunakan adalah The One Group Pretest-posttest Design. Pelaksanaan penelitian ini menggunakan desain kelompok tunggal dengan pretest dan posttest yang dilakukan dengan cara melakukan percobaan terhadap satu kelompok, tanpa menggunakan kelompok pembanding (Shaughnessy dkk, 2007). Rancangan ini dimaksudkan untuk mengetahui suatu pengaruh intervensi yang hasilnya diperoleh dengan cara membandingkan keadaan suatu kelompok sebelum diberi intervensi (pretest) dengan sesudah diberi intervensi (posttest). Pengukuran dilakukan sebelum dan sesudah intervensi diberikan. Perhitungan statistik yang diperoleh dari sebelum intervensi (pretest) dibandingkan dengan hasil setelah intervensi (posttest) yang kemudian digunakan untuk mengetahui ada tidaknya pengaruh intervensi tersebut. Menurut Campbell dan Stanley (Shaughnessy dkk, 2007), desain ini dimungkinkan dilakukan pada suatu penelitian dengan jumlah responden yang sedikit.

Pretest dilakukan sebelum proses intervensi untuk melihat kondisi awal peserta, yang dilakukan dengan menggunakan lembar observasi perkembangan motorik halus anak. Posttest dilakukan langsung setelah proses intervensi berakhir, dengan menggunakan lembar observasi perkembangan motorik halus anak yang sama dengan pretest sebagai evaluasi hasil proses intervensi.

Adapun rancangan penelitian dapat dilihat pada gambar berikut:

Keterangan :

$$
\mathrm{O} 1 \mathrm{X} \mathrm{O} 2
$$

O1 : Hasil observasi sebelum diberikan intervensi
"Lego")

$$
\text { X : Intervensi (Building Block }
$$

O2 : Hasil observasi setelah diberikan intervensi

Intervensi yang diberikan adalah berupa modul kursus Robokidz untuk level Kindergarten B (KGB) yang diberikan selama 2 bulan yaitu sejak bulan Desember 2019-Februari 2020. Modul diberikan secara mingguan, yang bertujuan untuk meningkatkan kemampuan motorik halus anak. Modul yang digunakan terdiri dari beberapa materi, yaitu :
a. LEGO Basic Brick Project
b. LEGO Education Project - Snake Lesson 2
c. LEGO Education Project - Snake Lesson 3
d. LEGO Education Project - Hens Project 1
e. LEGO Basic Brick Project
f. LEGO Education Project
g. LEGO Education Project
h. LEGO Basic Brick Project

Alat atau materi yang digunakan dalam penelitian ini adalah :
a. Lembar informed-consent penelitian
b. Lembar observasi kemampuan motorik halus anak usia 5-6 tahun berdasarkan Permendikbud No. 137 Tahun 2014
c. Modul Pre-Robotic untuk level KG-B dari Robokidz
d. Pedoman wawancara semi- terstruktur untuk mendapatkan data kualitatif

Analisis data yang digunakan untuk pengujian hipotesis penelitian ini adalah dengan analisis statistik, karena statistik bekerja dengan angka-angka yang bersifat 
objektif dan universal. Teknik analisis data yang digunakan adalah analisis kuantitatif dengan two related sample test dengan uji

\begin{tabular}{|c|c|c|c|}
\hline Perhitungan & $Z$ & $\begin{array}{c}\text { Signi } \\
\text { fikan } \\
\text { si (p) }\end{array}$ & $\begin{array}{c}\text { Keputu } \\
\text { san }\end{array}$ \\
\hline $\begin{array}{c}\text { Kemampuan } \\
\text { Motorik } \\
\text { Halus } \\
\text { (selisih } \\
\text { pretest- } \\
\text { posttest) }\end{array}$ & -1.414 & 0.157 & $\begin{array}{c}\text { Tidak } \\
\text { anifik } \\
\text { ast }\end{array}$ \\
\hline
\end{tabular}

Wilcoxon. Uji tanda merupakan bagian dari statistik non parametrik yang menguji dua sampel yang saling berhubungan (Priyatno, 2012). Selain itu dilakukan juga analisis data dengan cara naratif deskriptif. Analisis kualitatif bertujuan untuk memahami proses serta kemajuan yang dicapai oleh masingmasing peserta dan merupakan analisis yang digunakan untuk melengkapi analisis kuantitatif.

\section{Hasil dan Pembahasan}

Hasil penelitian dibagi menjadi dua bagian, yaitu hasil penelitian kuantitatif dan hasil analisis kualitatif.

\section{Hasil Analisis Kuantitatif}

Data yang diperoleh dari penelitian ini adalah nilai observasi kemampuan motorik halus pada saat sebelum (pre-test) dan setelah (post-test) intervensi.

Tabel 1. Deskripsi Data Kemampuan Motorik Halus

Berdasarkan data di atas, terdapat tren peningkatan kemampuan motorik halus pada anak setelah dilakukan pemberian building blocks "Lego" selama 8 minggu penelitian. Kondisi yang berbeda pada subjek Se yang tidak mengalami peningkatan dalam kemampuan motorik halus.

Uji Wilcoxon t-test untuk mengukur signifikansi perbedaan antara 2 kelompok data berpasangan berskala ordinal atau interval tetapi berdistribusi tidak normal. Hasil analisis menunjukkan bahwa tidak ada perbedaan kemampuan motorik halus yang signifikan pada subjek setelah dilakukan eksperimen.

Tabel 2. Hasil Uji Wilcoxon t-test untuk Kemampuan Motorik Halus Anak

Deskripsi data penelitian di atas menunjukkan bahwa hipotesis penelitian ditolak, yaitu building blocks "Lego" tidak meningkatkan kemampuan motorik halus anak usia dini secara signifikan.

Hasil Analisis Kualitatif

Data untuk deskripsi kualitatif diperoleh dari interpretasi kualitatif dari lembar observasi kemampuan motorik halus anak usia 5-6 tahun berdasarkan Permendikbud 137 Tahun 2014 dan wawancara pada guru. Adapun hasilnya adalah:

\section{$\underline{\text { Subjek An }}$}

\begin{tabular}{|c|r|r|r|}
\hline \multirow{2}{*}{ Subjek } & \multicolumn{2}{|c|}{ Pengukuran } & Selisih \\
\cline { 2 - 3 } & $\begin{array}{c}\text { Pre- } \\
\text { test }\end{array}$ & $\begin{array}{c}\text { Post- } \\
\text { test }\end{array}$ & $\begin{array}{c}\text { nilai } \\
\text { pre-post }\end{array}$ \\
\hline $\mathrm{An}$ & 4 & 6 & 2 \\
\hline $\mathrm{Se}$ & 3 & 5 & 2 \\
\hline $\mathrm{Sc}$ & 4 & 4 & 0 \\
\hline
\end{tabular}




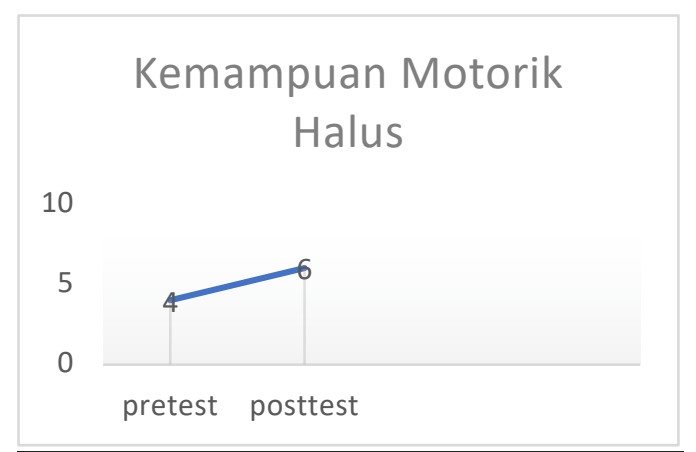

Gambar 1. Peningkatan Kemampuan Motorik Halus Subjek An

Subjek An berusia 5 tahun dan berada di TK B. Subjek telah cukup lama mengikuti kursus di Robokidz Samarinda. Sebelum perlakuan diberikan, subjek masih memerlukan motivasi dan bantuan dari guru untuk memasangkan beberapa keping lego agar dapat membuat karya yang sesuai dengan modul yang ada. Ia pun masih membutuhkan instruksi dari guru untuk menggunakan kepingan lego lainnya untuk digunakan menghias karya yang telah ia buat. Namun demikian, ia cukup mampu menyelesaikan tugas yang diberikan dengan cepat.

Setelah 8 minggu mengikuti eksperimen, subjek An mengalami peningkatan dalam kemampuan motorik halusnya. Ia sudah mampu mengerjakan karyanya sendiri sesuai dengan modul yang ada tanpa bantuan dari guru. Ia bahkan beberapa kali memberikan komentar bahwa tugas yang diberikan mudah untuk dikerjakan. Walaupun sebelumnya subjek tidak pernah melihat peternakan ayam, namun subjek mampu membuatnya dengan baik. Ia pun sudah mampu untuk menggunakan kepingan lego lainnya yang tidak terdapat dalam modul untuk menghias karyanya secara mandiri. $\underline{\text { Subjek Se }}$

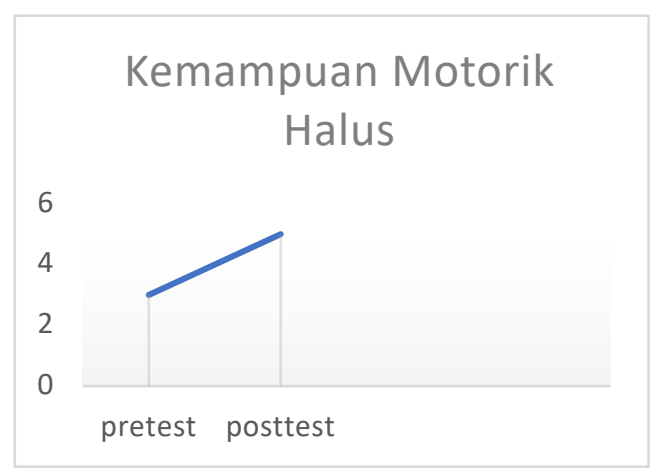

Gambar 2. Peningkatan Kemampuan Motorik Halus Subjek Se

Subjek Se berusia 5 tahun dan sudah mengikuti kursus di Robokidz Samarinda selama beberapa bulan. Sebelum perlakuan diberikan, subjek cukup mampu membuat karya dari kepingan lego sesuai dengan modul yang ada. Hanya saja, ia masih membutuhkan bantuan dari guru agar mampu membuat karya yang sesuai dengan modul yang ada. Ia pun belum mampu bereksplorasi dengan memanfaatkan keping lego selain yang disediakan oleh guru untuk menghias karya yang ia buat.

Setelah 8 minggu mengikuti eksperimen, subjek Se mengalami peningkatan dalam kemampuan motorik halusnya. Ia sudah mampu membuat karya sesuai dengan contoh yang ada di modul. 
Hanya saja, ia cenderung menolak untuk meniru bentuk yang ada di modul dan lebih suka membuat kreasi sendiri. Contohnya saat diminta membuat bentuk cupcake, subjek membuat cupcake burger, dan begitu seterusnya. Ia pun sempat beberapa kali terlihat bingung mengenai keping lego yang manakah yang akan ia gunakan untuk mengerjakan tugas. Dalam mengerjakan tugasnya, subjek masih membutuhkan bantuan dari guru. Subjek tidak membutuhkan bantuan sama sekali saat menghias karyanya dan bereksplorasi dengan keping lego yang lain yang tidak disediakan oleh guru. Ia mampu menghias karyanya sendiri secara kreatif dan melakukan modifikasi secara mandiri.

\section{$\underline{\text { Subjek Sc }}$}

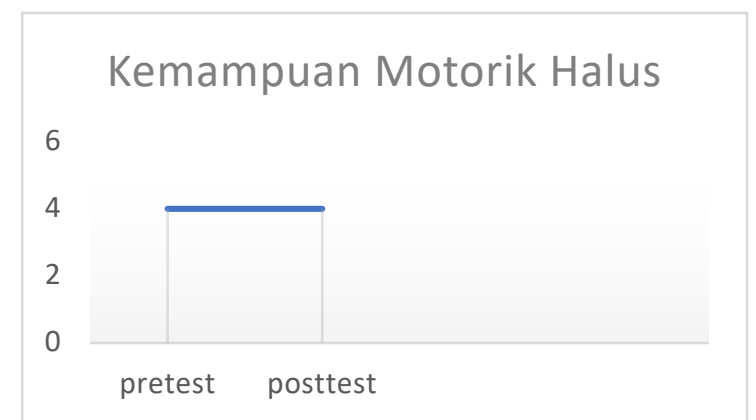

Gambar 3. Peningkatan Kemampuan Motorik Halus Subjek Sc

Subjek Sc berusia 6 tahun dan saat ini duduk di TK B. Ia telah mengikuti kursus di Robokidz Samarinda sejak sekolah di TK A selama 3 bulan, sebelum kemudian naik tingkat ke jenjang KG-B di Robokidz Samarinda. Subjek selalu membawa permen saat jam kursus dan selalu memakannya sebelum kegiatan dimulai. Sebelum eksperimen dilakukan, subjek cukup mampu menirukan bentuk lego di modul. Hanya saja, ia selalu membuat bentuk yang ia inginkan terlebih dahulu sebelum meniru bentuk yang terdapat di modul. Ia pun membutuhkan bantuan dan motivasi dari guru untuk menyelesaikan tugas yang diberikan. Ia seringkali bertanya keping manakah yang harus ia ambil dan gunakan untuk membuat karya yang sesuai dengan modul. Ia juga masih belum mampu bereksplorasi dalam menggunakan keping lego lain yang tidak disediakan untuk menghias karyanya.

Setelah 8 minggu eksperimen, subjek Sc tidak mengalami peningkatan dalam kemampuan motorik halusnya. Ia masih membutuhkan bantuan dan motivasi dari guru untuk membuat karya sesuai dengan modul yang ada. Ia pun seringkali diingatkan untuk tidak terburu-buru dalam mengerjakan oleh guru. Sepanjang kegiatan dilakukan, subjek banyak bergerak dan sering tersenyum. Kemampuan subjek dalam mengeksplorasi keping lego lain selain yang disediakan oleh guru belum meningkat. Ia bahkan cenderung menolak untuk menghias karyanya dan menolak melakukan modifikasi pada karya yang ia buat. Beberapa ide modifikasi yang ia buat tidak sesuai dengan tema yang ada pada modul dan pada akhirnya guru yang lebih banyak membuat modifikasi pada karya subjek.

Secara kuantitatif, hasil penelitian tidak mendukung hipotesis yang diajukan, yaitu tidak ada perbedaan yang signifikan pada kemampuan motorik halus anak usia dini sebelum dan sesudah eksperimen dilakukan. Namun demikian, pada analisis kualitatif, terdapat tren peningkatan pada kemampuan motorik halus pada 2 dari 3 subjek penelitian. Kemampuan motorik halus dipengaruhi oleh beberapa faktor (Rumini dan Sundari, 2004), yaitu: 
a. Faktor genetika, individu mempunyai beberapa faktor keturunan yang dapat menunjang kemampuan motorik halus misalnya otot kuat, syaraf baik, kecerdasan yang menyebabkan kemampuan motorik individu tersebut menjadi baik dan cepat.

b. Faktor kesehatan pada periode prenatal, janin yang selama dalam kandungan dalam keadaan sehat, tidak keracunan, tidak kekurangan gizi, tidak kekurangan vitamin dapat membantu mempelancar kemampuan motorik anak

c. Faktor kesehatan gizi, kesehatan dan gizi yang baik pada awal kehidupan pasca melahirkan akan mempercepat kemampuan motorik bayi.

d. Faktor rangsangan, adanya rangsangan bimbingan orang tua dan kesempatan anak untuk menggerakkan semua bagian tubuh akan mempercepat kemampuan motorik bayi.

e. Faktor kebudayaan, peraturan daerah setempat dapat mempengaruhi kemampuan motorik anak misalnya ada daerah yang tidak mengizinkan anak putri naik sepeda maka tidak akan diberi pelajaran naik sepeda roda tiga.

Pada subjek An dan Se, orangtua dan guru memberikan kesempatan pada anak untuk bereksplorasi dengan media lain selain building blocks "Lego" untuk mengembangkan kemampuan motorik halusnya. Hal ini terlihat dari kedua subjek yang sudah mampu memegang pensil dan menggunakan alat tulis dengan baik. Mereka juga sudah mampu menuliskan angka dan meniru bentuk yang terdapat di modul. Kemampuan mewarnai pun sudah cukup baik yang ditunjukkan dengan kerapian dalam mewarnai bentuk-bentuk yang terdapat pada modul yang disediakan oleh Robokidz. Sedangkan pada subjek Sc, ia cenderung lebih banyak menolak saat diminta untuk berkreasi dan lebih suka menggunakan kepingan yang disediakan saja.

Senada dengan hal tersebut, Hurlock (Yenny, 2017) mengatakan bahwa hal penting dalam mempelajari kemampuan motorik adalah adanya kesempatan belajar dan kesempatan berpraktek. Ketiga subjek mendapatkan kesempatan belajar yang cukup luas. Hal ini terlihat dari kenyataan bahwa mereka tidak hanya mengikuti pendidikan formal di jenjang Taman KanakKanak, namun juga mengikuti kursus robotic di Robokidz Samarinda. Perbedaan kemampuan motorik halus yang dimiliki oleh ketiga subjek lebih banyak dipengaruhi oleh kesempatan berpraktek. Ketiga subjek mendapatkan kesempatan belajar dan berpraktek yang sama di Robokidz Samarinda. Akan tetapi, subjek Sc cenderung tidak bersedia untuk berpraktek dan bereksplorasi lebih luas walaupun diberikan kesempatan dan bahkan didorong oleh guru. Hal ini berbeda dengan subjek An dan Se yang mengambil kesempatan untuk berekplorasi dengan bebas menggunakan building blocks "Lego" yang tersedia di Robokidz Samarinda.

Salah satu cara dalam mengembangkan kemampuan motorik halus anak dapat dilakukan dengan cara yang menyenangkan bagi anak usia dini yaitu dengan cara bermain. Menurut Hurlock (2000) bermain ialah setiap kegiatan yang dilakukan untuk kesenangan yang ditimbulkannya, tanpa mempertimbangkan hasil akhir. Bermain building blocks "Lego" merupakan salah 
satu aktivitas yang dapat menjadi pilihan. Anak mendapatkan banyak manfaat dari permainan ini, baik dalam hal kemampuan motorik halus, kreativitas, daya tahan, dan juga konsistensi. Walaupun penelitian ini belum menunjukkan hasil yang signifikan secara kuantitatif, namun secara kualitatif terdapat tren peningkatan dalam kemampuan motorik halus anak usia dini. Faktor-faktor yang mendukung penelitian ini adalah para subjek yang memang memiliki kesenangan dalam menggunakan permainan building blocks "Lego". Faktor lain yang mendukung adalah guru-guru yang sangat kooperatif dan mendorong anak untuk berpraktek menggunakan kepingkeping "Lego" yang ada untuk mengembangkan kemampuan motorik halus, daya imajinasi, dan kreativitas mereka.

Penelitian ini memiliki keterbatasan, yaitu dalam hal penggunaan lembar observasi yang belum menggambarkan secara keseluruhan kemampuan motorik halus anak. Selain itu, kehadiran anak dalam sesi kursus di Robokidz juga sangat mempengaruhi hasil dari penelitian ini. Hal lain yang dapat menjadi masukan bagi peneliti selanjutnya adalah perlunya menggali data mengenai kebiasaan anak di rumah dalam memainkan permainan building blocks "Lego" yang dapat mempengaruhi perkembangan motorik halus anak.

Pada dasarnya, penggunaan building blocks "Lego" dapat menjadi salah satu metode untuk meningkatkan kemampuan motorik halus anak usia dini. Namun demikian, dalam pelaksanaannya, permainan ini membutuhkan supervisi dari orang dewasa untuk mendorong dan memotivasi anak untuk berpraktek dan melakukan eksplorasi.

\section{Kesimpulan}

Penggunaan building blocks "Lego" tidak menunjukkan pengaruh yang signifikan pada peningkatan kemampuan motorik halus anak usia dini. Meskipun demikian, secara kualitatif, penggunaan permainan ini menunjukkan tren peningkatan pada kemampuan motorik halus pada 2 dari 3 subjek penelitian. Hal ini disebabkan dalam pengembangan kemampuan motorik halus, selain perlu adanya kesempatan belajar, juga diperlukan kesempatan berpraktek agar kemampuan yang ada dapat meningkat dan kemudian menjadi sebuah keterampilan pada anak. Penelitian ini sangat dipengaruhi oleh kesempatan berpraktek yang ternyata tidak dilakukan oleh semua subjek. Terdapat satu orang subjek yang menolak untuk melakukan eksplorasi lebih jauh sehingga ia pun tidak mengalami peningkatan dalam kemampuan motorik halusnya.

\section{Ucapan Terima Kasih}

Penulis mengucapkan terima kasih kepada Lembaga Penelitian dan Pengabdian Masyarakat Universitas Widya Gama Mahakam Samarinda yang telah memberi bantuan dana untuk kegiatan penelitian ini.

\section{Daftar Pustaka}

Hurlock, E. B. (2000). Perkembangan Anak. Jakarta : Erlangga.

Martuti. (2008). Mengelola PAUD. Yogyakarta : Kreasi Wacana

Priyatno, D. (2012). Cara Kilat Belajar Analisis Data dengan SPSS 20. Yogyakarta: Andi Offset.

Putri, N. P. R.U., Antara, P. A., Tirtayani, L. A. (2016). Pengaruh Permainan Konstruktif Terhadap Kemampuan Motorik Halus Anak Kelompok A2 
Rabaitulmutaallim Tegalinggah Singaraja. e-Journal Pendidikan Anak Usia Dini Universitas Pendidikan Ganesha Jurusan Pendidikan Guru Pendidikan Anak Usia Dini (Volume 4. No. 3 - Tahun 2016). Diunduh dari https://ejournal.undiksha.ac.id/index .php/JJPAUD/article/download/872 5/5676.pdf

Rumini, S., Sundari, S. (2004). Perkembangan Anak dan Remaja. Jakarta : Rineka Cipta.

Shaughnessy, dkk. (2007). Metode Penelitian Psikologi. Yogyakarta: Pustaka. Pelajar.
Widiyanti, D. (2016). Peningkatan Keterampilan Motorik Kasar Anak Usia 5-6 Tahun Melalui Teknik Tari, diunduh dari www.rmolbengkulu.com pada 8 Oktober 2019.

Yenny. (2017). Gambaran Perkembangan Motorik Anak Usia 5-6 tahun yang Bermain Games Gadget. Prosiding Temu Ilmiah X Ikatan Psikologi Perkembangan Indonesia. 